\title{
Exotic plants in small islands: Implications for tourism destination management in Gili Trawangan and Gili Air, Lombok
}

\section{Luchman Hakim}

Department of Biology, Faculty of Mathematics and Natural Sciences, Brawijaya University Malang, East Java luchman@ub.ac.id

\section{Sun-Kee Hong (corresponding author)}

Institution for Marine and Island Cultures, Mokpo National University, Korea

landskhong@gmail.com

\author{
Hilman Ahyadi \\ Department of Biology, Faculty of Mathematics and Natural \\ Sciences, Mataram University, Mataram, West Nusa Tenggara, \\ Indonesia \\ ahyadi.kelautan@gmail.com
}

Publication Information:

Received 22 March 2017, Accepted 21 May 2017, Available online 28 June 2017

doi: $10.21463 /$ jmic.2017.06.1.04

\section{Abstract}

The aim of the study is to analyze the diversity of exotic plant species in a small tourist island in Lombok, West Nusa Tenggara. A field study was conducted at Gili Trawangan and Gili Air, West Nusa Tenggara. Tourism is the main activity in these islands, buttourism infrastructure development, garden landscaping and theintroduction of exotic plant species have caused dramatic changes in the vegetation of these small islands. A total of 108 non-native plant species of 44 families was recorded, demonstrating the high number of exotic plant species that have been introduced. The family with the highest number of species was Fabaceae, followed by Asparagaceae, Arecaceae, Apocynaceae, Euphorbiaceae, Anacardiaceae, and Myrtaceae. Native plant species have decreased as a consequence of tourism infrastructure development. Exotic plant species represent culturally and economically important resources in Gili Trawangan and Gili Air. Many native species in Gili are useful for food, construction material, ornaments, remedies, and forage. Exotic plant species are planted as ornaments, as well as for shade, ground cover, hedges and fences, and as focal points. Some important aspects should be considered in order to minimize the impact of exotic plant species upon native ecosystems, including plant species regulation, plant monitoring, and restoration of degraded habitats and encouraging the growth of local flora as acomponent of garden landscaping in the tourism infrastructure. Sustainable gardening may consist of 
establishing an agroforestry system to guarantee continuing small island ecosystems and rehabilitating the abandoned farmlands.

\section{Keywords}

exotic plant species, tourism risk, sustainable small island, Lesser Sunda

\section{Introduction}

There are many reports on the effects of exotic plant species on local biodiversity. Exotic plant species are introduced into numerous places for economical reasons, or to help in habitat recovery and improvement. The rate at which many exotic plant species are introduced is correlated closely with development activity. Scholars point out, however, that many exotic plant species are potentially invasive (Keane \& Crawley, 2002; Allendorf \& Lundquist, 2003; Callaway \& Ridenour, 2004), leading to the degradation of native vegetation. The exotic invasive plant species are distinguished from massive weeds growing in the natural ecosystem, the agro-ecosystem, abandoned lands or unmanaged man-made habitats (Sakai et al., 2001; Gurevitch \& Padilla, 2004). In Indonesia, exotic and invasive plant species are widespread in abandoned lands. There are also reports concerning the invasion of exotic plants in protected areas, including national parks. An example of the negative impact of exotic plant species invasion can be found in the case of Acacia nilotica in Baluran National Park, East Java. Eupatorium inulifolium, in particular, has increased in occurrence as an exoticinvasive plant in many national parks (Whitten et al., 1996; Hakim et al., 2005).

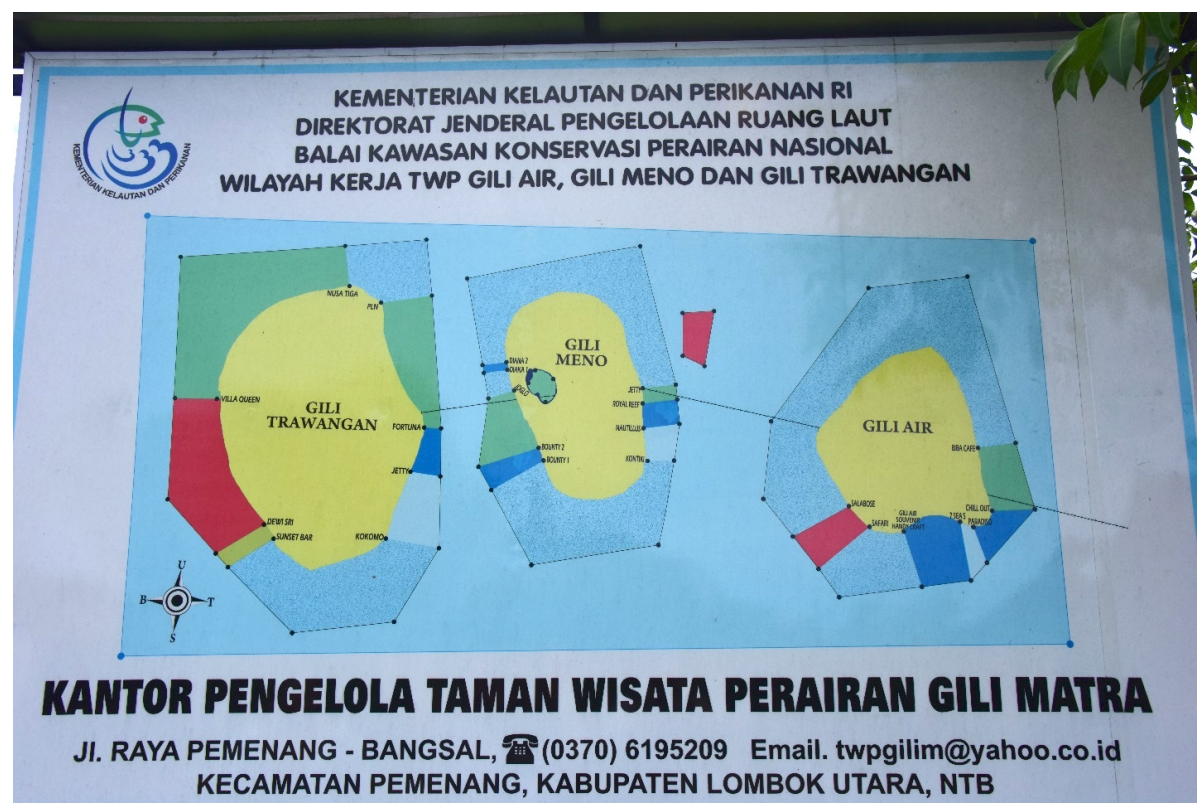

Fig 1. Location of Gili Air and Gili Trawangan, Lombok (photo by S.-K. Hong) 
Gili Trawangan and Gili Air in West Lombok Island (West Nusa Tenggara) harbor diverse marine creatures. These islands, together with Gili Meno, were declared as a marine nature recreation park in 1993. The underwater biodiversity and wide white sandy beaches are significant tourist attractions in the Gili Islands (Cushnahan, 2001; Hampton \& Hampton, 2009). In these small islands, the trend toward marine tourism is growing significantly and attracting many investors to provide and establish numerous tourism facilities, including accommodation. Local people's participation in tourism has also increased, and many private houses have been transformed into homestays. Tourism developers prefer to build substantial tourism accommodations and infrastructure in the coastal area (Kamsma \& Bras, 2002; Kurniawan et al., 2016). In order to increase the visual quality of landscapes and increase the availability of food, numerous plants have been introduced to the islands. However, little emphasis has been placed on studying exotic plant species in small island tourism destinations. The identification of the present nature and extent of exotic plant species is an important first step in small island conservation. This information is also useful for the further quantification of the ecological and economical impact of exotic and invasive species.

\section{Methods}

\section{Study Area}

Gili Trawangan, Gili Meno, and Gili Air administratively belong to the Nusa Tenggara Barat Province. Ecologically, these island sare rich in terms of marine biodiversity and are famous as nature-based tourism destinations. The area of Gili Trawangan is about 336,24 ha and Gili Air about 169,73 ha. According to the Schmid Ferguson climate classification, the types of climate in the islands are $C$ and $D$. The average rainfall is $1000 \mathrm{~mm}$; and the temperature ranges from 20$30^{\circ} \mathrm{C}$. The recent vegetation of the islands is determined partly by cultural and partly by climatic factors (Monk et al., 2012). The landscapes of Gili are dominated by shrubland and semiarid forest with patchy vegetation, in which Lanneacoromandelica is dominant and easily found in all parts of the islands. Gili Trawangan is a habitat for some birds, including Treronvernans, Pycnonotus aurigaster, Pycnonotus goiavier, Acridotheres ginginianus and Megapodius reinwardt. The Ministry of Forestry Decree No. 99/Kpts-II/2001 on March 15, March 2001, declared Gili Air, Menoand Trawangan as a Marine Recreation Park with an area of about 2.954 ha (BKSDA NTB, 2003).

\section{Methods}

A floristic exploration was carried out during September 2015 and January 2016 at Gili Trawangan and Gili Air. A field survey was carried outalong the island's inhabited corridors. These corridors are dominated by tourist accommodation, bars, restaurants, local orchards, and houses and homestays. The purpose of the survey was to identify and record ornamental and cultivated plants. We interviewed some people from each island, asking about the history of the island, past vegetation and the recent existence of exotic plant species in Gili.

Identification was carried out directly in the field, based on morphological characteristics. The taxonomic identity of each specimen was identified according to guidelines provided by Riffle (1998), Whistler (2000), and Greig (2004).

Geographical distribution, to assess the origins of species, was determined using online database information from the 
U.S. National Plant Germplasm System (https://npgsweb.ars-grin.gov). Raunkiaer's classification of plant species was used to identify the plant-environment interaction. The main group of the classifications is: Phanerophytes, Chamaephytes, Hemicryptophytes, Cryptophytes and Therophytes. We were also able to gather information related to land conservations.

\section{Results}

\section{Tourism development in the Gili Islands}

Before the development of tourism, Gili Trawangan and Gili Air were inhabited by local fishermen from South Sulawesi. These islands were established as tourism destinations over a decade ago; the main tourism attractions include the diversity of marine living creatures and the wide sandy beaches. Tourism activities includediving, snorkeling, sunbathing and canoeing. Recently, tourism accommodation has grown to occupy a large area in the coastal areas of the islands. Seaside hotels and other accommodation provide much more open space for sport, sunbathing, and sports activities.

Table 1. Tourism accommodation and facility in Gili Trawangan and Gili Air

\begin{tabular}{|c|c|c|c|c|c|}
\hline \multirow{2}{*}{ No } & \multirow{2}{*}{ Tourist facility } & \multicolumn{2}{|r|}{ Gili Trawangan } & \multicolumn{2}{|r|}{ Gili Air } \\
\hline & & Unit & No. of workers & Unit & No. of workers \\
\hline 1 & Hotel and homestay & 200 & 1963 & 69 & 241 \\
\hline 2 & Café and restaurant & 85 & 735 & 45 & 216 \\
\hline 3 & Bar & 33 & 100 & 21 & 55 \\
\hline 4 & Swimming pool & 50 & 74 & 11 & 12 \\
\hline 5 & Art shop & 26 & 26 & 2 & 3 \\
\hline 6 & Live music and convention facility & 2 & 20 & 1 & 4 \\
\hline 7 & Spa, salon and fashion & 12 & 55 & 2 & 3 \\
\hline
\end{tabular}

According to our informants, in the past, the vegetation of Gili Trawangan and Gili Air was similar to that of undisturbed small islands in the Lombok area. Located in a semiarid environment, Gili Trawangan and Gili Air are generally considered to have a low diversity of plant species, but little is known about the past flora diversity and vegetation structure. The most abundant tree species is probably the Santen, Lanneacoromandelica. In Gili Trawangan and Gili Air, the establishment of tourist accommodation (hotels, restaurants, leisure places) is noticeably associated with a decrease in native vegetation and an increase of exotic plant species, which have been introduced mainly as ornamental plants. Developers view ornamental plants as a crucial decoration for tourist accommodation. With the rapid 
development of tourism infrastructure and facilities in the coastal area, a new ecosystem has developed. The native coastal forest has decreased and the tourism infrastructure and facilities have increased.

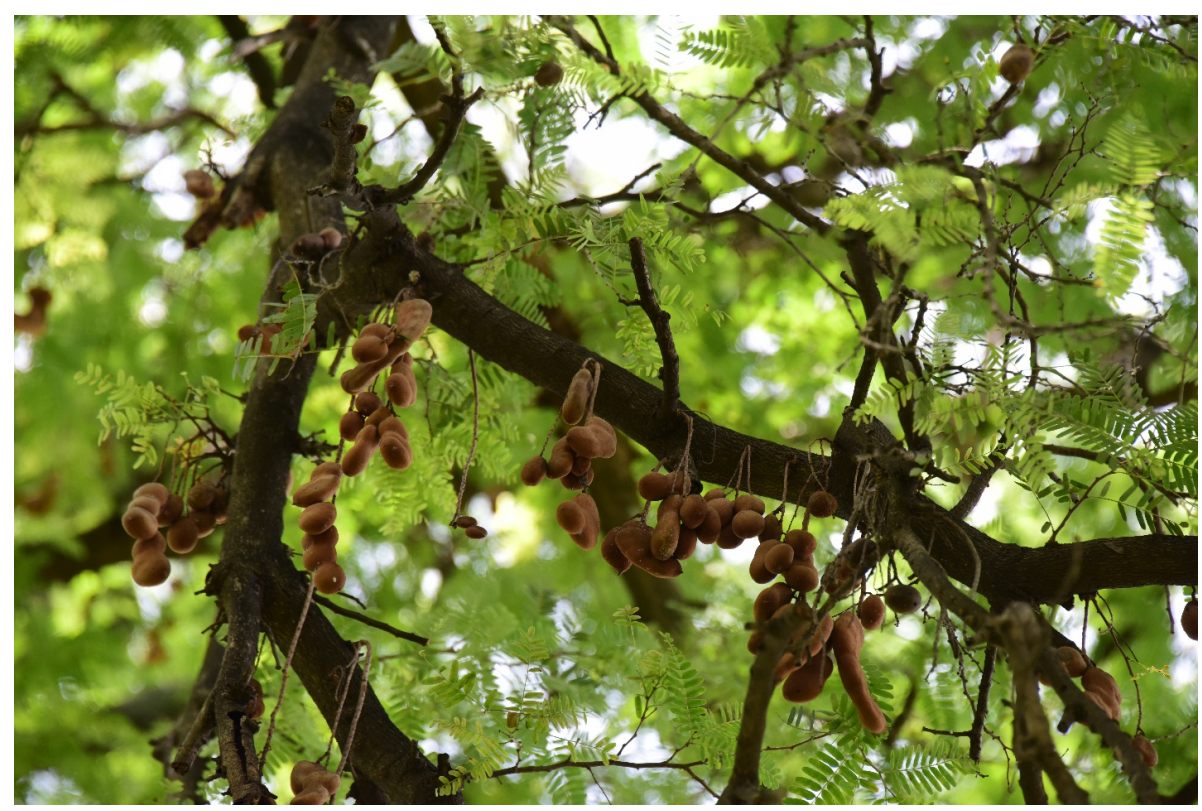

Fig 2. Tamarind tree at Gili Air, Lombok (photo by S.-K. Hong)

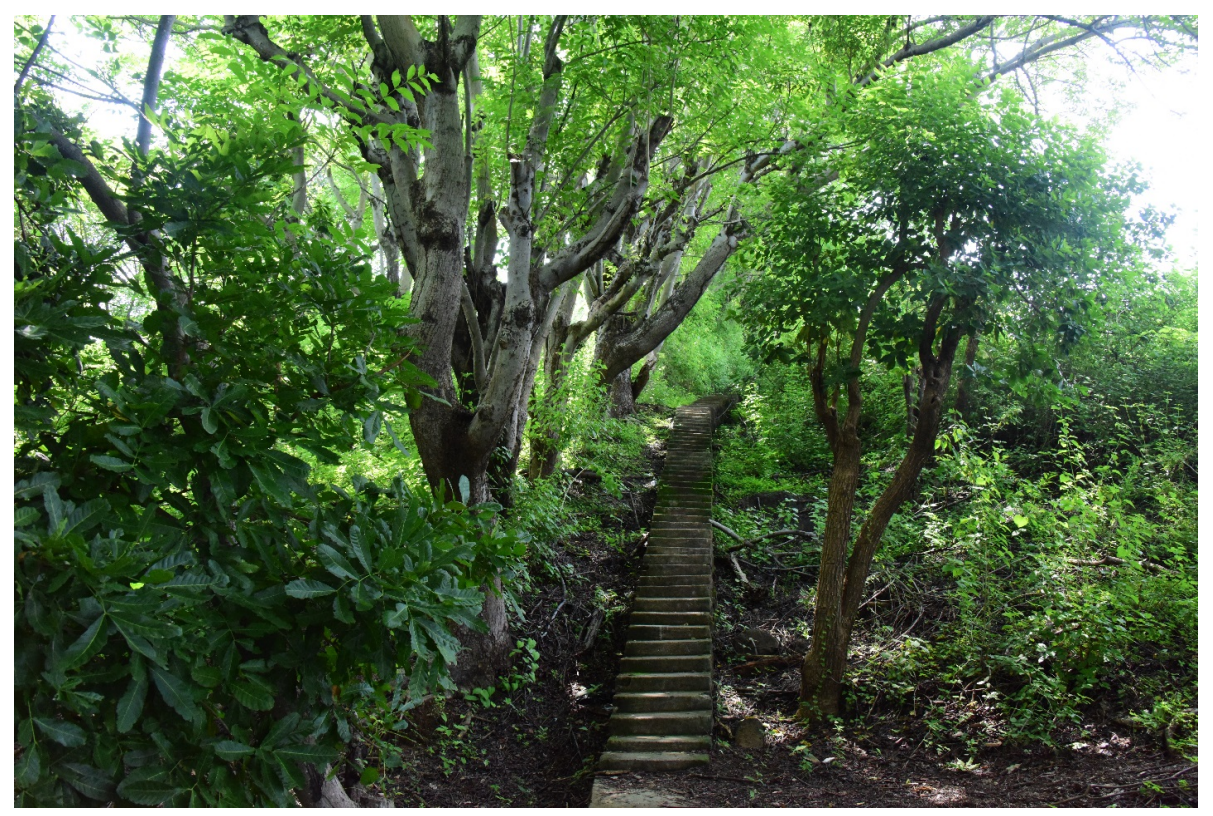

Fig 3. Spondias species at Gili Trawangan, Lombok (photo by S.-K. Hong) 


\section{Recent native species}

Mangrove plants are absent and the entire coastal area was dominated by lowland coastal forest. Recently, however, few native plant species are apparent in the coastal area; the rapid growth of tourism infrastructure seems to be responsible for this. According to our informants, prior to development, the coastal area contained native coastal vegetation, including Pemphisacidula, Scaerotafrustescens, Hibiscus tiliaceus, Crinum asiaticum, Terminalia catappa, Calophyllum inophyllum, Tamarindus indica, Cocos nucifera, Barringtonia asiatica, and Pandanus tectorius. Specialist sandy coastal tree species include Casuarina equisetifolia and Terminalia catappa. These species are common in tropical regions (Whitten et al., 1996).

The remaining native vegetation is also foundon the hills of the island. Hillside species consist of $L$. coromandelica, Ricinus communis, Melia azedarach, Schleicheraoleosa and Moringa oleifera; these are subjected to severe cultural and economic interference, particularly by livestock grazing. The population of $L$. Coromandelica in the uplands of Gili produces abundant forage for goats. Some drought tolerant plant species were found, including Borassus flabellifer and Corypha utan. Scholars point out that these are the principal plant species in semiarid landscapes in the Lesser Sunda Islands and have been known as persistent pioneers in semiarid regions (Monk et al., 2012; Eagleton, 2016). Ficus benjamina and Ficus septica are probably native to both islands. Some open areas were dominated by grasses and shrubs. Cocos nucifera is the most common palm, both in Gili Air and Gili Trawangan. Cocos nucifera is a multipurpose palm tree. The principal grass is Imperata cylindrica, which can grow on poor soils and abandoned land, and is successful in areas that are frequently burned (MacDonald, 2004).

Recently, L. coromandelicahas become a dominant species in Gili ecosystems. L. coromandelica is found in all types of land use: as a shade tree in local settlements and roads, as a live fence and as forage. It can be propagated easily by vegetative techniques, and is tolerant of drought and poor soils, and is fire resistent (Chapa, 1992). Under the massive pressure of tourism infrastructure and facility development, the likelihood of native plant seedlings growing to adult trees has been relatively low. Regeneration is also impeded by long dry periods, poor soil nutrients, and grazing. Seedlings of native species are also sensitive to anthropogenic disturbances.

\section{Exotic plant species}

\section{Recent exotic plant species}

The first phase of plant species introduction seems to be related to staple food and forage species. Plants introduced into the islands to provide staple foods include Musa paradisiaca, Manihot esculenta, and Ipomoea batatas and, for vegetables, Carica papaya, Sechium edule, Vigna unguiculata, Artocarpus heterophyllus, Moringa oleifera and Capsicum annuum. Forage species include Sesbania grandiflora and Leucaena leucocephala. The number of ornamental plants was limited, and plants serving economical purposes were widely found. Many ornamental plant species were apparently introduced in the 2000s when tourism started to grow rapidly in Gili Trawangan and Gili Air. Recently, a total of 108 nonnative plant species of 44 families were found in Gili Air and Gili Trawangan. The family with the highest number of species was Fabaceae (11 species), followed by Asparagaceae (9 species), Arecaceae (6 species), Apocynaceae (7 species), Euphorbiaceae (6 species), Anacardiaceae (5 species) and Myrtaceae (5 species). Some species have many cultivars; for example, cultivars of Cordyline fruticosa include Cordyline Rosebud, Cordyline Suzie's Choice, Cordyline 
Nigra and Cordyline Hawaiian Sunset, and cultivars of Codiaeum variegatum include Ann Rutherford's Croton, Picasso's Paintbrush Croton, Croton Petra, Gold Dust, and Thai Croton. Nyctaginaceae has one species, Bougainvillea spectabilis, that shows a variety of flower and leaf structure, and colors of pink, purple, red, violet, white and yellow. Durantaerectahas four cultivars, namely Durantaerecta Golden Edge, Duranta erecta Variegata, Duranta erecta Alba, and Duranta erecta Sheena's Gold.

With increased tourism, exotic plant species have appeared. Accommodation facilities in small islands use numerous exotic plant species as ornamental plants. The process underlying ornamental plant introduction is largely related to aesthetic landscaping. Garden landscaping aims for impact and usually involves large numbers of ornamental plants (Riffle, 1998;Whistler, 2000; Greig, 2004).

Based on Raunkiaer's classification, exotic species can include the categories Phanerophytes (Mesophanerophytesand Microphanerophytes), Chamaephytes, Hemicryptophytes and a few numbers of Cryptophytes (Table 2). There are no Megaphanerophytes (plants with a height $>30 \mathrm{~m}$ ) found. The tallest species is probably $20-25 \mathrm{~m}$ in height. The number of Cryptophytes - perennial plants with the resting bud underground - was limited. Recent plant classification figures reflect clearly the interactions between plant and environment, and the physical characteristics of land and local climates in the Gili Islands seems to influence and contribute to the vegetation profiles (Danin,\& Orshan, 1990; Woodward \& Cramer, 1996).

Table 2. The floristic life-form spectrum of exotic species in Gili Air and Gili Trawangan

\begin{tabular}{|l|l|l|l|l|}
\hline \multicolumn{2}{c}{ Raunkiaer's classification } & \multicolumn{1}{c|}{ Gili Air } & \multicolumn{2}{c|}{ Gili Trawangan } \\
\cline { 2 - 6 } & \multicolumn{1}{|c|}{ No. of sp. } & $\%$ & \multicolumn{1}{c|}{ No. of sp. } \\
\hline Phanerophytes & & & & \\
\hline Megaphanerophytes & 0 & 0 & 0 & 0 \\
\hline Mesophanerophytes & 21 & 22 & 13 & 20 \\
\hline Microphanerophytes & 18 & 19 & 14 & 22 \\
\hline Nanophanerophytes & 0 & 0 & 0 & 0 \\
\hline Chamaephytes & 31 & 33 & 20 & 31 \\
\hline Hemicryptophytes & 18 & 19 & 16 & 25 \\
\hline Cryptophytes & 7 & 7 & 1 & 2 \\
\hline Total species & 95 & & 64 & \\
\hline
\end{tabular}

There are 51 exotic plant species found on both islands. Most of these species are drought resistant, including Anacardium occidentale, Plumeria acuminate, Cocos nucifera, Eupatorium inulifolium, Cactaceae, Euphorbia milii, Ricinus communis, Bauhinia purpurea, Samanea saman, Tectona grandis and Bougainvillea spectabilis. The presence of forage species on both islands, including Leucaena leucocephala, Sesbania grandiflora, and Gliricidia sepium, indicates the importance of the species for livestock feeds. 
Most of the species originated from outside the Malesian hytoregion; only a few species come from the Asia tropical and Malesian region, including Mangifera indica, Polyscias scutellaria, Bauhinia purpurea, Sesbania grandiflora, Artocarpus heterophyllus, Moringa oleifera, Etlingera elatior and Schleicheraoleosa. Averrhoa carambola seems to be native to Java Island. Many species were introduced from Africa, the Asia-temperate region, and America. Crinum asiaticum, Cocos nucifera, Calophyllum inophyllum and Terminalia catappa have the widest distribution, ranging from Africa, AsiaTemperate, Asia-Tropical, Australasia, and the Pacific. The wide geographical origins of species indicate that the environment of Gili Island is able to accept the arrival and establishment of exotic plants. This is crucial for plant colonization and invasion in the future (Richardson et al., 2000; Allendorf \& Lundquist, 2003).

\section{Category of plant use}

Data on plant utility shows the numerous reasons for the introduction of plants; many species in Gili were useful for food or construction materials, or as ornaments, remedies, and forage.

Food

Rice is the main carbohydrate source in Gili Islands and arrived from Lombok Island. There are, however, some species cultivated in home gardens and orchards. The valuable staple food species found in these islands is Ipomoea batatas and Manihot esculenta. Vegetable species include Sauropus androgynous, Capsicum annuum, Sechium edule, Gnetum gnemon, Artocarpus heterophyllus, Carica papaya and Sesbania grandiflora. Common fruit tree species include Persea americana, Averrhoa carambola, Psidium guajava, Syzygium aqueum, Anacardium occidentale, Mangifera indica, Artocarpus heterophyllus, Carica papaya, Musa paradisiaca, Manilkara zapota, Annona muricata, and Annona squamosa. Some fruit species, however, are less consumed, including Manilkara kauki.

\section{Construction materials}

The principal species used forconstruction includes Tectona grandis, Artocarpus heterophyllus, Swietenia macrophylla, and Cocos nucifera. Except for Bambusa bambos, bamboo species used as building materials (Dendrocalamus asper, Gigantochloa apus, Gigantochloa atter) are not found in any areas of Gili Air and Gili Trawangan. There is no data or information related to the absence of these bamboo species in the islands.

\section{Ornamental}

Ornamental plant species have been used to increase the beauty and attractiveness of the environment. Functionally, ornamental plants can be classified into three categories according to their functions: (1) shade plants, (2) ground cover, (3) hedges/fences, and (4) focal point species.

- Shade plants. Shade plants are especially important to reduce light penetration and include trees producing fruits and flowers. Species with huge canopies include Samanea saman and Manilkara zapota. Samanea saman was not found in any part of the settlement area, especially in areas with a high housing density. Other shade plant species include Mangifera indica, Cananga odorata, Artocarpus heterophyllus, Artocarpus altilis and Syzygium aqueum. The canopy of the trees is able to decrease air temperature.

- Ground cover. Ground cover plants are low-growing species and are usedfound for hotels and homestays with open areas and adequate sunlight. Ground cover species include Hymenocallis sp., Sansevieria trifasciata, and 
Lantana camara. Napier grass, Pennisetum purpureum, is planted as a ground cover in many local homestays. In tropical environments, surface damage and disturbance are serious problems; ground cover plants can play an important role in the protection of the soil surface from erosion. Many species of grasses and herbs are used to increase surface protection and reduce rain runoff.

- Hedges/fences. In the orchards and plantation areas, the commonest plants for fences include Gliricidia sepium, L. coromandelica, Ricinus communis, Moringa oleifera, and Leucaena leucocephala. Herbs which are often planted as fences in traditional houses include Sauropus androgynus and Hibiscus schizopetalus. Other ornamental plants used as fences include Durantaerecta, Heliconia, Hibiscus schizopetalus, Pseudosasa japonica and Codiaeum. The species often used for hedging for local houses, guest houses, and restaurants and hotels encompasses Sansevieria trifasciata, Etlingera elatior, and Rhapis excelsa. There is also Heliconia, which has been extensively used as hedging for tourism accommodation and is now probably dominant. The Heliconia fencing species include Heliconia rostrata, Heliconia collinsiana, Heliconia latispatha and Heliconia psittacorum. The varieties of Heliconia are distinguished by differences in their flowers. There are several varieties of Cordyline, all distinguished by differences in their leaf structure and color. These species, especially the tall plants, make beautiful living boundaries and give the feeling of an outdoor room.

- Focal point species. These comprise single or multi species that attract people's attention because of their beauty and uniqueness. Accommodation complexes contain particularly large numbers of colorful ornamental plant species. In hotels and restaurants, a wide range of ornamental plant species are planted including Caesalpinia pulcherrima, Agave variegata, Adenium obesum, Plumeria acuminate, Codiaeum variegatum, Heliconia, Ixora paludosa, and Erythrina crista-galli. There are a number of plants originating from America that are not native to tropical regions, for example, Cactaceae, used as focal point species in the front yard of local community houses.

The beauty and uniqueness of exotic plant species are influenced by the diverse character of their flowers, leaves, fruit, and clump morphology and plant architecture (Table 3).

Table 3. Flower characteristic

\begin{tabular}{|l|l|l|}
\hline \multicolumn{1}{|c|}{ Part of interest } & \multicolumn{1}{c|}{ Gili Air (\%) } & Gili Trawangan (\%) \\
\hline Flower & 30 & 26.37 \\
\hline Leaf & 33 & 23.33 \\
\hline Flower-leaf & 5 & 3.4 \\
\hline Fruit & 25 & 12.17 \\
\hline Clump & 5 & 4.6 \\
\hline All parts of plant & 2 & 2.3 \\
\hline
\end{tabular}

\section{Remedies}

Only few community members now practice traditional medicine. Nevertheless, some of the plants in Gili Trawangan and Gili Air could be used as medicines, and have been used thus in many local communities in Indonesia. Some exotic plant 
species are important sourcesof medicines, including Annona muricata, Psidium guajava, Citrus aurantiifolia, Sauropus androgynous and Morinda citrifolia. The direct use of plants for medicines was observed in many local communities (Sheng-Ji, 2001), but not in the local population in Gili Air and Gili Trawangan. Home gardens are the core habitats for plant species with potential medical value; these gardens, belonging to local people, are biologically rich and contain a variety of medical plant species.

\section{Forage}

Many forage plant species are drought tolerant. The common forage species is Lanneacoromandelica. Some forage plants species, such as Leucaena leucocephala and Sesbania grandiflora, are cultivated in the upland areas. In Gili Trawangan and Gili Air, home gardens and local plantations are notable sites for their high forage species diversity. The foliage of these plants is important to support livestock in rural areas of developing countries (Van Eys et al., 1986). The use of perennial grasses for forage is limited and cows are absent in Gili Trawangan and Gili Meno. However, goats are abundant and this seems to be related to the feed availability in the islands.

The numerous forms of plant usage in Gili Trawangan and Gili Air suggest that local people are aware of the roles of plants in their daily life and are likely to be interested in gardening and maintaining plants. Gardening is now becoming popular, especially among households who are involved in tourism, for example, running homestays, shops or restaurants.

\section{Weeds}

Some exotic plant species are important weeds in the island ecosystem. Eupatorium inulifolium is a wild shrub originating from South America. Today, E. inulifolium is the main invasive species in Indonesian national parks, such as Bromo Tengger Semeru, Baluran, Alas Purwo and Meru Betiri. Eupatorium inulifolium was originally a southern coastal species in South America but it was introduced into Java Island and spread as invasive species. In many areas, $E$. Inulifolium is the main contributor to biodiversity decline (Hakim et al., 2005; Hakim, 2011).

In Gili Trawangan and Gili Air, E. inulifolium is found in less well-attended home gardens, community plantations, and abandoned lands. Although E. inulifolium is not planted in the abandoned lands, this species often colonizes these areas. The population of $E$. inulifolium increases under a minimal forest canopy. Imperata cylindrica is considered as an invasive weed in Gili Trawangan and Gili Air; it is a perennial rhizomatous grass species found inabundance in open areas and areas with less canopy (MacDonald, 2004). Other significant weeds include Phyllanthus urinaria and Lantana camara.

\section{Implications for environmental management in small islands}

With increased tourism to Gili Island, the tourism infrastructure has grown, resulting in disturbances to the native vegetation, loss of coastal biodiversity and disruption of biological food webs (Gössling, 2002; Davenport \& Davenport, 
2006). The increase in exotic plant species in Gili Island is mainly a result of tourism accommodation development. Tourism development in Gili is not only potentially destroying the native vegetation and plant species but is also potentially responsible for altering the landscape of Gili. Conservation planning and objectives in Gili Island focus exclusively on marine creature protection but rarely address the conservation of the land environment. The main challenges facing present conservation involve terrestrial conservation as an integral part of the Gili Trawangan-Gili Meno-Gili Air conservation area.

Many tourists and tour operatorshave become increasingly aware of environmental degradation. There have been many campaigns focused on sustainable and responsible tourism practices. The environmental movement for responsible travel represents a significant attention into future tourism destination management (Medina, 2005). With regard to the recent situation of exotic plant species in the Gili ecosystem, some measures should be taken in order to minimize their impact on native ecosystems. These measures include:

\section{Regulation}

There are no regulations related to species introduction into small islands. There is a need to put in place administrative processes when plant species are introduced into small island ecosystems. This may be achieved by involving local government, local scientific authorities and universities, the local community and tourism stakeholders in intensive discussion regarding the regulation of plant introduction. The development of these regulations is an important early step to mitigate exotic plant invasiveness.

\section{Monitoring}

We suggest the introduced species population in small islands should be monitored. The selection of ornamental plant species is generally determined by the availability of open space around hotels, restaurants, and homestays. Ornamental plant diversity is greatly affected by the way ornamental plants are arranged in these spaces. Most tourism accommodation developers have a policy of garden landscaping improvement to maintain accommodation attractiveness; the use and proliferation of the exotic plants introduced should be monitored in terms of their effect on the local ecosystem.

\section{Restoration}

The restoration of abandoned lands is crucial. Restoration is the process to assist the recovery of a degraded ecosystem. In the case of Gili Trawangan and Gili Air, it includes the rehabilitation of the coastal area damaged by tourism infrastructure development.Restoration of these areas includes, but is not limited to (1) clearing exotic plant species, (2) improving the coastal area through the re-introduction of native vegetation, and (3) involving people in restoration programs. Determining the place and restoration approach in Gili Trawangan and Gili Air is a potential subject for debate in the local community, local government, practitioners, and developers. A detailed survey of past vegetation, land characteristics, land ownership, and socio-cultural aspects is, therefore, essential in the initial stages of restoration programs (Higgs, 2003). 


\section{Encouraging local flora}

Much local flora has unique characteristics which may be incorporated into garden landscaping in Gili Trawangan and Gili Air. Local flora provides habitats and shelter for small mammals, birds, and insects which are important to maintain local ecosystem stability. Local flora is important in maintaining soil structure and compositions and therefore contributes to the sustainability of the small island ecosystem. Encouraging local flora is particularly challenging because many local species are still unidentified.

\section{Gardening culture improvement}

This study shows that gardening, done mainly by women, is a popular human activity in these small islands. This activity does not require specific techniques or a large amount of time. Gardening has increased the number of species in Gili Trawangan and Geli Air but has also caused a negative impact on the island ecosystems.

Interviews revealed that there are some problems related to gardening related to a large number of introduced plant species. In each local community in Gili Trawangan and Gili Air, problems exist concerning the management of sustainable gardening practices. Generally, watering ornamental plants to enhance their performance is a problem, especially in dry months. Many ornamental herbs wilt, wither and their leaves fall. In dry periods, many plants are home to numerous insect pests. Some species were reported to grow rapidly and require intensive clearing by physically cutting back the plant. There were no reports of herbicide usage, but this may change in the future.

There is a need to improve the gardening culture in these small islands. Agroforestry, by involving native vegetation and mixing crops with three species, seems feasible. Agroforestry is one of the sustainable agriculture farming approaches used in Indonesia, and in many dry environments, it is becoming the solution for sustainable agriculture and environmental conservation. In the case of Gili Trawangan and Gili Air, the introduction of agroforestry seems a viable tool to enhance the sustainability of the island ecosystems. Agroforestry has a potentiality to integrate into the tourism sector (Hviding \& Bayliss-Smith, 2000) and consequently open new opportunities for tourism attraction diversification, both in Gili Trawangan and Gili Air. 


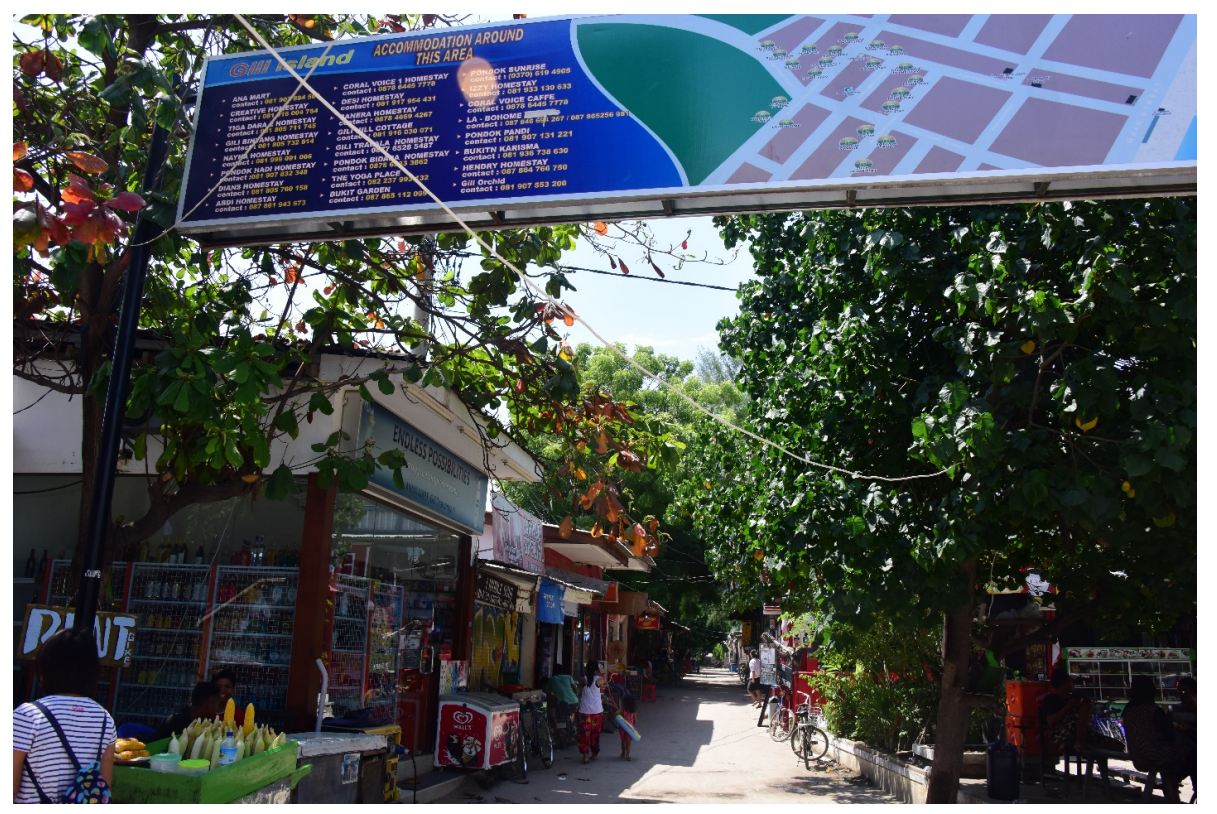

Fig 4. Intrusion and expanding local market and accomodation in Gili. Need land planning for tourism and nature coservation (photo by S.K. Hong)

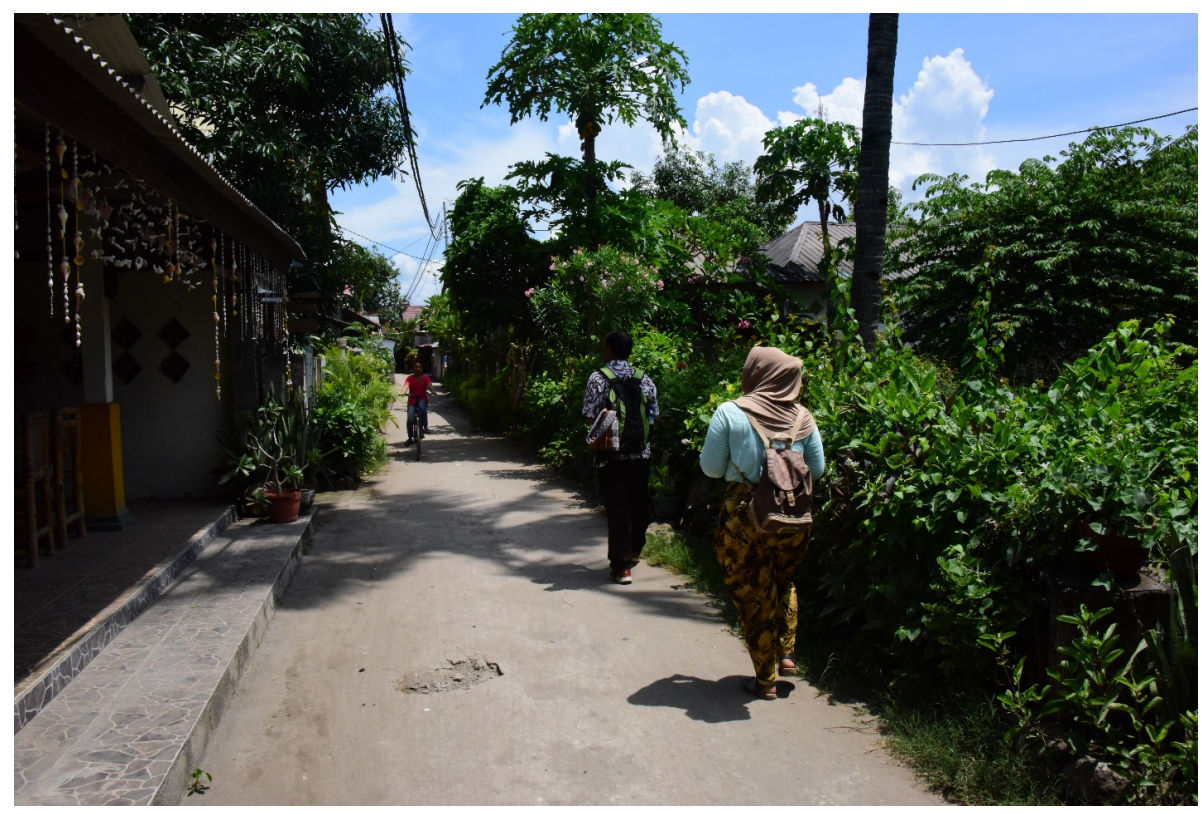

Fig 5. Fences used by native plants are recommeded for protecting local fauna and flora (Gili Air, photo by S.-K. Hong) 


\section{Conclusion}

Gili Trawangan and Gili Air are now identified as areas that manifest a diversity of exotic plant species. Environmental, economic and social aspects contribute to making exotic species easy to introduce into the island ecosystem. There is a clear relationship between the value of exotic plant species and attempts to attract tourists. The use of exotic plant species in Gili Trawangan and Gili Air is associated with tourism accommodation (hotels, cottages, restaurants, and homestays). Changes in vegetation and plant species may affect the sustainability of a small island ecosystem. For sustainable island tourism destination management, it is essential to minimize the introduction of exotic plant species into small islands by means of plant species regulation, plant monitoring, restoration of degraded habitats and encouraging local flora as a component of garden landscaping. From an environmental perspective, destination management plans could also incorporate sustainable gardening that is implemented by local people, tourism accommodation managers, and owners, in the small islands.

\section{Acknowledgements}

This paper was supported by the National Research Foundation of Korea Grant funded by the Korean Government (MEST) (NRF-2009-361-A00007).

\section{References}

Allendorf, F. W., Lundquist, L. L., 2003. Introduction: population biology, evolution, and control of invasive species. Conservation Biology, 17(1), 24-30.

BKSDA NTB, 2003. Profil Taman Wisata Laut Gili Matra, Nusa Tenggara Barat, Mataram.

Callaway, R. M., Ridenour, W. M., 2004. Novel weapons: invasive success and the evolution of increased competitive ability. Frontiers in Ecology and the Environment, 2(8), 436-443.

Chapa, D. R., 1992. Propagation of Lannea coromandelica. Banko Janakari, 3(3), 27-28.

Cushnahan, G., 2001. Resource use and tourism on a small Indonesian island. Tourism Recreation Research, 26(3), 25-31.

Danin, A., Orshan, G., 1990. The distribution of Raunkiaer life forms in Israel in relation to the environment. Journal of vegetation science, 1(1), 41-48.

Davenport, J., Davenport, J. L., 2006. The impact of tourism and personal leisure transport on coastal environments: a review. Estuarine, Coastal and Shelf Science, 67(1), 280-292.

Eagleton, G. E. 2016., Persistent pioneers; Borassus L. and Corypha L. in Malesia. Biodiversitas 17(2), 716-732.

Gössling, S. 2002., Global environmental consequences of tourism. Global environmental change, 12(4), 283-302.

Greig, D. 2004., Ornamental Foliage Plants. Firefly Books-New Holland Publisher (UK). 
Gurevitch, J., Padilla, D. K., 2004. Are invasive species a major cause of extinctions?. Trends in Ecology \& Evolution, 19(9), $470-474$.

Hakim, L., Leksono, A. S., Purwaningtyas, D., Nakagoshi, N., 2005. Invasive plant species and the competitiveness of wildlife tourist destination: A case of sadengan feeding area at Alas Purwo National Park, Indonesia. Journal of International Development and Cooperation, 12(1), 35-45.

Hakim, L., 2011. Cultural Landscapes of the Tengger Highland, East Java. In Landscape Ecology in Asian Cultures (pp. 69-82). SpringerTokyo. Hampton, M., Hampton, J., 2009. Is the Beach Party Over? Tourism and the Environment in Small Islands: a Case Study of Gili Trawangan, Lombok, Indonesia. Tourism in Southeast Asia: Challenges and new directions, 286.

Higgs, E., 2003. Nature by design: people, natural process, and ecological restoration. MIT Press.

Kamsma, T., Bras, K., 2002. Gili Trawangan-from desert island to 'marginal'paradise. In Tourism and Sustainable Community Development (Eds. G. Richards and D. Hall), Roudledge.

Keane, R. M., Crawley, M. J., 2002. Exotic plant invasions and the enemy release hypothesis. Trends in Ecology \& Evolution, 17(4), 164-170.

Kurniawan, F., Adrianto, L., Bengen, D. G., Prasetyo, L. B., 2016. Vulnerability assessment of small islands to tourism: The case of the Marine Tourism Park of the Gili Matra Islands, Indonesia. Global Ecology and Conservation, 6, 308-326.

MacDonald, G. E., 2004. Cogongrass (Imperata cylindrica)-biology, ecology, and management. Critical Reviews in Plant Sciences, 23(5), 367380.

Medina, L. K., 2005. Ecotourism and certification: Confronting the principles and pragmatics of socially responsible tourism. Journal of Sustainable Tourism, 13(3), 281-295.

Monk, K. A., De Fretes, Y., Reksodiharjo-Lilley, G., 2012. Ecology of Nusa Tenggara and Maluku (Vol. 5). Tuttle Publishing.

Richardson, D. M., Pyšek, P., Rejmanek, M., Barbour, M. G., Panetta, F. D., West, C. J., 2000. Naturalization and invasion of alien plants: concepts and definitions. Diversity and distributions, 6(2), 93-107.

Riffle, R.L., 1998. The Tropical Look: An encyclopedia of Landscape Plants for Wordwide Use. Thames and Hudson - Timber Press, Hong Kong.

Sakai, A. K., Allendorf, F. W., Holt, J. S., Lodge, D. M., Molofsky, J., With, K. A., Baughman, S., Cabin, R.J., Cohen, J.E., Ellstrand, N.C., McCauley, D. E., O'Neil, P., Parker, I.M., Thompson, J.N.,Weller, S.G., 2001. The population biology of invasive species. Annual review of ecology and systematics, 32(1), 305-332.

Sheng-Ji, P., 2001. Ethnobotanical approaches of traditional medicine studies: some experiences from Asia. Pharmaceutical biology, 39(sup1), 74-79.

Van Eys, J. E., Mathius, I. W., Pongsapan, P., Johnson, W. L., 1986. Foliage of the tree legumes gliricidia, leucaena, and sesbania as supplement to napier grass diets for growing goats. The Journal of Agricultural Science, 107(2), 227-233.

Whitten, A. J., Soeriaatmadja, R. E., Afiff, S. E. 1. A., 1996. The ecology of Java and Bali, the ecology of Indonesia series Vol II. Periplus Editions, Singapore.

Whistler, W. A., 2000. Tropical ornamentals: a guide. Timber Press (OR).

Woodward, F. I., Cramer, W., 1996. Plant functional types and climatic change: introduction. Journal of Vegetation Science, 7(3), $306-308$.

Hviding, E., Bayliss-Smith, T., 2000. Islands of rainforest: agroforestry, logging and eco-tourism in Solomon Islands. Ashgate Publishing Ltd. 